\title{
PUBLIC PERCEPTION OF THE POLICY OF BANNING EID AL- FITR IN 2021 IN BOGOR REGENCY
}

\author{
Muhamad Alfi Auliya Rachman \\ RS Family Medical Center \\ Jl. Buncit Raya No.15, Jakarta Selatan \\ E-mail: alfiauliyarachman@gmail.com
}

\begin{abstract}
Introduction: Homecoming is a social phenomenon in Indonesia every year. To prevent the spread of the Covid-19 virus, the Government makes a Policy to Eliminate Homecoming for Eid Al-Fitr in 2021. Objective: To determine public perceptions regarding the ban on going home for Eid in 2021. Methods: This study uses a survey method with a quantitative questionnaire conducted at the Type C Hospital in Bogor Regency with a sample of 84 respondents. Results: respondents aged 30-40 years agreed not to go home for Eid with a presentation of 80\%, over 40 years of age $75 \%$ agreed and $25 \%$ did not agree. Conclusion: During the Covid-19 Pandemic, greatly affects people's perceptions of traveling back and forth. The majority of respondents agreed to the 2021 Eid homecoming ban due to concerns about contracting or transmitting the Covid-19 virus. Recommendations: There are strict sanctions for violators who continue to go home, scouring the location of crowds during the Eid transportation period, the community continues to maintain health and comply with the Health Protocol.
\end{abstract}

Keywords : Covid-19, Homecoming, Big Scale Social Restriction 
E-ISSN: 2808-5361 http://e-journal.fkmumj.ac.id/
Proceeding The First

Muhammadiyah

Internasional- Public Health and Medicine Conference

\section{INTRODUCTION}

A pandemic is a disease that occurs globally. The World Health Organization (WHO) states that a pandemic is declared when a new disease spreads rapidly around the world beyond limits. Meanwhile, according to the KBBI, a pandemic is an epidemic that spreads simultaneously everywhere covering a wide geographical area. The Covid-19 virus began to become an epidemic in December 2019 which then spread throughout the world until now, so this Covid-19 outbreak has become a problem in all countries in the world.

Based on sources obtained until April 2021 regarding the number of Covid 19 cases globally, there were $141,057,106$ confirmed patients and 3,015,043 patients who died. Meanwhile, in Indonesia, the number of patients who were confirmed was 1,609,300, patients

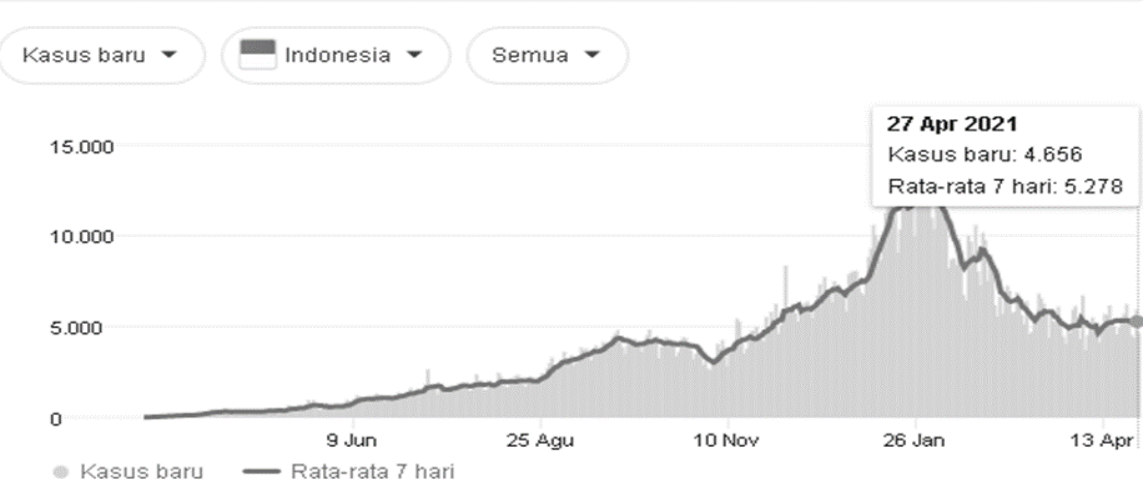

recovered 1,461,414 and patients died 43,567.

Picture. 1

To prevent the spread and transmission of the Coronavirus from spreading into the community, the government has made a series of policies to handle it. Some of the policies made by the government are written, and some are not. For example, Law Government Regulation, Government Regulation, Presidential Regulation, Ministerial Regulation, Regional Regulation, Regent Regulation, Mayor Regulations and others including Decrees, and letters from the government. While the unwritten policies are unwritten invitations from the government, community leaders, traditional leaders, cultural leaders, religious leaders, which contain prohibitions and appeals related to the prevention and handling of COVID-19.

From Picture 1, it can be seen that the graph of the number of Covid 19 cases in Indonesia until April 27, 2021, there were 4,656 new cases. The total number of COVID-19 cases in Indonesia until April 27, 2021, was 1.65 million, 1.51 million were cured and 44,939 cases died. 
During the COVID-19 pandemic, big cities are not only nodes of economic activity, but also nodes of the spread of COVID-19. High human mobility in urban areas is now a major factor in the spread of COVID-19. Several studies have shown that human mobility is primarily caused by the spread of the epidemic.

In this context, the homecoming also known as Mudik/Pulang Kampung is a phenomenon it has the potential to spread the COVID-19 virus. In addition to restrictions on activities outside the home, restrictions on traveling are also carried out by the Government to protect its citizens from the threat of the spread of the Covid-19 virus, one of which is the issuance of regulations regarding the prohibition of Homecoming Ied Fitr 2021. With the hope, this homecoming ban policy can reduce the number of cases and break the chain of transmission of Covid 19 spread in Indonesia.

\section{MEHODS}

Survey method using a questionnaire as a research instrument and collecting data using quantitative research methods. Location at FMC Bogor Hospital, one of the Type C Hospitals in Bogor Regency on April 1 - May 1, 2021 patient's as many as 84 respondents.

\section{RESULTS AND DISCUSSIONS}

With the government regulations for breaking the spread of the Covid 19 virus, such as lockdown, PSBB, and the ban on Homecoming, it should be able to increase public awareness in this pandemic era. The role of the community in breaking the chain of Covid-19 is urgently needed, this disease must be watched out for because of its rapid transmission, and the death rate is also high, especially in someone who has a history of previous illness and the vulnerable, namely the elderly, children and the patients who have the immunocompromised condition.

The largest homecoming flow is expected to occur from Jakarta to Central Java. Jabodetabek is the largest sending area for travelers/immigrants, while Central Java and East Java are the largest receiving provinces, respectively (Ari Purwanto Sarwo Prasojo, 2020). In previous research, it was found that the percentage of Jabodetabek people who plan to travel back and forth fell to $23.93 \%$ during the Pandemic period (Muhtaruddin, 2020).

Homecoming has a big potential danger because travelers are not necessarily free/immune from the virus, especially the Covid-19 virus. Travelers have the potential to become carriers from areas that have been exposed to Covid-19 can arise due to the high flow of homecoming to an area. This is evidenced by the fact that the island of Java, which is estimated to be the largest area as a recipient of homecomers, has now become a new epicenter of the 
spread of Covid-19 and occupies the top 5 regions with the highest number of positive cases in Indonesia (Gugus Tugas Percepatan Penanganan COVID-19, 2020)

If people don't keep their social distancing, and it is known that the person is being infected or a carrier of the virus, then this has the potential to transmit to others and spread again the others (Leo Agustino, 2020). However Indonesian government in such a way makes several policies to suppress the increase in Covid-19 cases, one of the government policies discussed in this study is related to the ban on going home (Homecoming) for Eid in 2021, where if the homecoming ban is carried out As much as possible, it is hoped that the Covid-19 case will be reduced.

Table 1.1 The characteristics of the respondents which include the age of 84 respondents from the age range of 30-40 years and above 40 years.

\begin{tabular}{|c|c|c|}
\hline Age & Sample & Percentage \\
\hline $30-40$ y.o & 42 & $50 \%$ \\
\hline$>40$ y.o & 42 & $50 \%$ \\
\hline
\end{tabular}

Tabel 1.2 Responded Answers

\begin{tabular}{|c|c|c|c|c|}
\hline \multirow{2}{*}{ QUESTION } & \multicolumn{3}{|c|}{ AGE } \\
\cline { 2 - 5 } & \multicolumn{2}{|c|}{$<\mathbf{4 0}$ y.o } & \multicolumn{2}{c|}{$>\mathbf{4 0}$ y.o } \\
\cline { 2 - 5 } & YES (\%) & NO (\%) & YES (\%) & NO (\%) \\
\hline $\begin{array}{c}\text { Do you agree with the travel ban policy } \\
\text { to stop the spread of the virus that causes } \\
\text { COVID-19? }\end{array}$ & $80 \%$ & $20 \%$ & $75 \%$ & $25 \%$ \\
\hline $\begin{array}{c}\text { Do you agree that homecoming (mudik) } \\
\text { can increase s the spread Covid-19 virus? }\end{array}$ & $85 \%$ & $15 \%$ & $90 \%$ & $10 \%$ \\
\hline $\begin{array}{c}\text { Carry out the Government's } \\
\text { recommendation for not doing } \\
\text { Homecoming for Eid 2021? }\end{array}$ & $90 \%$ & $10 \%$ & $85 \%$ & $15 \%$ \\
\hline
\end{tabular}

From the table presented above, it can be concluded that the majority of those aged 3040 years agree not to go homecoming for Eid with a percentage of $80 \%$. People who do not agree with the policy because their current permanent residence is in their hometown. Meanwhile, the main reason for respondents to cancel or not to go home was because they were worried that they would be infected or transmit the Covid-19 virus to their family. Meanwhile, at the age of 40 years, $25 \%$ do not agree with the policy. They still expect the policy abolished because they want to meet their children, grandchildren, and other relatives during Eid time. 
It can be seen that the knowledge of the respondents about reducing and stop the spread of the virus COVID-19 is good. This conclusion was obtained from the survey results which showed the average answer "yes" was above $70 \%$.

\section{CONCLUSION AND SUGGESTIONS}

The Covid-19 pandemic affected people's perceptions of Homecoming Eid Fitr 2021. The majority of respondents agree with Implementation because they are concerned about the spread and transmitted virus during Homecoming They believe if there is a family cluster during Ied Fitr 2021 many bad things will happen, meanwhile Health facilities \& healthcare services are frequently difficult to access in rural areas so it will make difficult to handle Covid19 patients. However, the efforts to prevent and monitor the spread of Covid-19 must continue so there will not be an increase in the number of cases of Covid 19 after Eid is over.

There is punishment for travelers who still carry out homecoming such as turning back and fines if needed. Screening in the locations that have the potential for crowds during the Eid transportation period, such as terminals, stations, airports, and inter-city borders.

During the COVID-19 pandemic, it is hoped that the community will maintain good health and immunity by implementing a healthy lifestyle such as consuming vitamins, getting a good rest, increasing the consumption of water to at least 2 liters per day, and still carry out health protocols such as wearing masks, wash hands, etc.

\section{REFERENCES}

Gugus Tugas Percepatan Penanganan Covid-19 Tahun 2020 Tentang Kriteria Dan Persyaratan Orang Dalam Masa Adaptasi Kebiasaan Baru Menuju Masyarakat Produktif Dan Aman Corona Virus Disease 2019 (Covid-19)

Implementasi Peraturan Walikota Bogor Tentang Pembatasan Sosial Berskala Besar Dalam Penanganan Covid-19. Hasti Erning Praja, Fakultas Hukum Universitas Ibnu Khaldun Bogor. Jurnal Program Mahasiswa Kreatif. 2020

Kebijakan Pemerintah Dalam Penanganan Pandemi Covid-19. Darmin Tuwu.Ilmu Kesejahteraan Sosial FISIP Universitas Halu Oleo. Journal Publicuho. Vol :3. 2020

Pengaruh Implementasi Kebijakan Terhadap Efektivitas Penanggulangan Covid-19 Oleh Pemerintah Daerah Kabupaten Kerinci. Idham Imam Seputra. Program Studi Manajemen Pemasyarakatan, Politeknik Ilmu Pemasyarakatan, Indonesia. NUSANTARA: Jurnal Ilmu Pengetahuan Sosial. Vol : 7. 2020 
Pengaruh Pendemi Covid-19 Terhadap Persepsi Masyarakat Jabodetabek Untuk Melakukan Perjalanan Mudik. Muhtaruddin. Jurnal Penelitian Transportasi Darat. Vol:22. 2020:

Potensi Pola Aliran Mudik Pada Masa Pandemi Covid-19 (THE POTENTIAL OF "MUDIK" FLOWS PATTERNS IN COVID-19 PANDEMIC). Ari Purwanto Sarwo Prasojo. Jurnal Kependudukan Indonesia. 2020 